PRZEGLĄDY - POLEMIKI - MATERIAEY

Kwartalnik Historyczny Rocznik CXXIV, 2017, 3 PL ISSN 0023-5903

PRZEMYSEAW P. SZPACZYŃSKI

Zielona Góra

\title{
HABSBURGOWIE I JAN ZAMOYSKI WOBEC AMBICJI MOCARSTWOWYCH ZYGMUNTA III*
}

Na wstępie pragnę wyrazić podziękowanie Edwardowi Opalińskiemu za tak wnikliwą prezentację mojej książki ${ }^{1} \mathrm{w}$ artykule recenzyjnym, tym bardziej że w dwóch kwestiach niezwykle ważnych dla „sprostowania”, żeby użyć określenia Recenzenta, negatywnego wizerunku Zygmunta III w historiografii, przyznaje on mi rację. Po pierwsze, gdy pisze, że „Autor przedstawił wiele istotnych argumentów na poparcie tezy, że król nie prowadził polityki prohabsburskiej, ale że starał się relacje z domem cesarskim traktować instrumentalnie" (0794). Mit o prohabsburskiej polityce Zygmunta III funkcjonuje wszak w polskiej historiografii jako ugruntowany stereotyp. Druga kwestia zaś jest znacznie ważniejsza, a mianowicie Recenzent uznaje, iż opowiadając się „za nieużywaniem przydomku Waza w stosunku do Zygmunta III i jego synów”, słusznie uważam, „że to Jagiellonowie po kądzieli” (0778). Nie dostrzega jednak przy tym negatywnej roli, jaką ów niemający żadnego odzwierciedlenia w źródłach przydomek pełni w polskiej histografii w odniesieniu do Zygmunta III i jego synów, zwracając uwagę, iż „z drugiej strony warto zauważyć, że przydomek Wazowie podkreśla ciągłość panowania tej swoistej dynastii w monarchii elekcyjnej" (0778).

Otóż w Szwecji po raz pierwszy przydomku „Waza” użyto dopiero w 1786 r. i to nie w odniesieniu do Zygmunta bynajmniej, tylko do

* W odpowiedzi na artykuł recenzyjny Edwarda Opalińskiego, Zygmunt III wobec Habsburgów i Jana Zamoyskiego, KH 123, 2016, 4, s. 777-795 (stąd kolejne cytaty, oznaczone w tekście O).

${ }^{1}$ P.P. Szpaczyński, Mocarstwowe dążenia Zygmunta III w latach 1587-1618, Kraków 2013 (oznaczone w tekście S). 
jego szwedzkiego dziadka Gustawa I Ericssona - założyciela szwedzkiej dynastii. Szwedzki biograf króla Gustawa podkreśla, że zbitka „Gustaw Waza", choć dziś bardzo rozpowszechniona w Szwecji, w rzeczywistości jest „anachronizmem”, a określenie „król Waza” nazywa wprost ,jeszcze gorszym dziwactwem"2. To, co jednak w szwedzkiej historiografii jest anachronizmem i dziwactwem, to w polskiej jest normą od wydania w 1984 r. popularnonaukowej biografii Zygmunta III „Wazy” autorstwa Henryka Wisnera, który w przekonaniu, że „Waza” to nazwisko króla, kwestionuje nawet, że to przydomek ${ }^{3}$.

Historycy polscy ewidentnie nadużywają od ponad trzydziestu lat określenia „Waza” w odniesieniu do Zygmunta III i jego synów w przekonaniu, że to nazwisko rodowe króla, i tym samym utwierdzają owo błędne przekonanie w odbiorze społecznym. Błędne, ponieważ „Waza” to nie było nazwisko jak chociażby Sobieski czy Batory, gdyż królowie określani dziś potocznie „dynastią Wazów”, nigdy sami „Wazami” się nie nazywali, ani też nie byli tak nazywani. Ba, oni nigdy o takim nazwisku nie słyszeli! Nie ma ani jednego źródła, w którym znaleźlibyśmy określnik „Waza”, nie mówiąc już o zbitkach typu „Zygmunt III Waza”, „Zygmunt Waza”, „Jan Waza”, „ród Wazów” „pierwszy Waza”, „młody Waza” itp.

Mój sprzeciw wobec tego przydomku bierze się również stąd, iż wprost zniesławia on Zygmunta III, ma wszak na celu podkreślenie, że król był przede wszystkim Szwedem, obcym, że nie Polskę czy Litwę uważał za swoją ojczyznę, lecz jedynie Szwecję, o czym jest przekonany biograf króla Wisner, a co pozostaje w ewidentnej sprzeczności ze źródłami ${ }^{4}$. Ów przydomek ma też na celu odcięcie Zygmunta III i jego synów od Jagiellonów, do których historykom uprzedzonym do króla wnuk wnuka Jagiełły i jego synowie urodzeni i wychowani w Polsce, noszący imiona po jagiellońskich przodkach, nie pasują $a^{5}$. Wprost przeciwstawia się ich nie tylko Jagiellonom, określając „Wazami”, ale i „królom rodakom”, aby w sposób tendencyjny podkreślając ich rzekomą obcość, utwierdzać o tym przekonanie w odbiorze społecznym ${ }^{6}$.

${ }^{2}$ L.O. Larsson, Gustaw Waza. Ojciec państwa czy tyran?, Warszawa 2009 (oryg. szw. 2002), s. 6, 21, 75.

${ }^{3}$ H. Wisner, rec.: Przemysław Szpaczyński, Mocarstwowe dążenia Zygmunta III w latach 1587-1618, Kraków 2013, OiRwP 58, 2014, s. 260-266; H. Wisner, Kilka słów odpowiedzi Przemysławowi P. Szpaczyńskiemu, OiRwP 60, 2016, s. 224.

${ }^{4}$ P.P. Szpaczyński, Odpowiedź Henrykowi Wisnerowi na recenzję, OiRwP 60, 2016, s. 216.

${ }^{5}$ O tym, że „Dzisiaj może nas wręcz drażnić nieustanne wówczas odwoływanie się do tradycji dynastii jagiellońskiej, żywej dzięki synowi Katarzyny Jagiellonki”, J.A. Chrościcki, Sztuka i polityka. Funkcje propagandowe sztuki w epoce Wazów 1587-1668, Warszawa 1983, s. 40.

${ }^{6}$ U. Augustyniak, Wazowie i ,królowie rodacy”. Studium władzy królewskiej w Rzeczypospolitej XVII wieku, Warszawa 1999. 
Określenie „Jagiellonowie po kądzieli” podkreśla ciągłość panowania dynastii polsko-litewskiej, która bynajmniej nie wygasła w $1572 \mathrm{r}$. z chwilą śmierci Zygmunta II Augusta, jak to przyjęło się w historiografii. Historycy ewidentnie zdają się zapominać, że ósmym królem z dynastii Jagiellonów była Anna I Jagiellonka. To zapominanie i lekceważenie Anny I w historiografii polskiej również nie bierze się znikąd, ale z faktu, że przeforsowała na tron Zygmunta wbrew kanclerzowi Janowi Zamoyskiemu, który w ocenie większości polskich historyków był po śmierci Batorego bardziej odpowiednim kandydatem do tronu polskiego niż wnuk wnuka Jagiełły?

Do Zygmunta III nie pasują historykom również dążenia mocarstwowe króla, tymczasem nie brak świadectw źródłowych, które potwierdzają tego typu ambicje potomka Jagiellonów. Po pierwsze, nie może być wątpliwości, iż Zygmunt III chciał połączyć Szwecję-Finlandię i Rzeczpospolitą pod swoim berłem, a więc utworzyć władztwo od Laponii po Morze Czarne. Tak rozległym terytorium jak Zygmunt III w latach 1592-1599 nie władał nigdy żaden król polski i niewielu władców europejskich. Oba królestwa Zygmunta III od początku miał łączyć sojusz nie obronny, lecz zaczepny skierowany przeciw Moskwie, która od drugiej połowy XV w. prowadziła agresywną ekspansję kosztem zjednoczonej ze Szwecją Finlandii i kosztem zjednoczonej z Polską Litwy. Chodziło wszak nie tylko o to, żeby się zabezpieczyć przed dalszą ekspansją wschodniego sąsiada we wspólnym sojuszu, ale żeby Moskwie to, co zabrała, odebrać, a nawet pójść jeszcze dalej i prowadzić ekspansję na wschód, aż do rozbioru państwa carów. Tego ostatniego faktu historycy polscy uprzedzeni do Zygmunta III i lekceważący jego ojca Jana III uparcie dostrzec nie chcą, podczas gdy wiedzą o tym doskonale na podstawie źródeł historycy szwedzcy i rosyjscy.

I tak dla przykładu szwedzki autor najnowszej (przetłumaczonej w 2011 r. na język polski) biografii ojca Zygmunta III - Jana III, Lars Ericson Wolke w rozdziale "Plany ekspansji i długi konflikt z Rosją" w podrozdziale „Imperialne ambicje Jana III na wschodzie” pisze: „Priorytety Jana III w polityce zagranicznej obejmowały w pierwszym rzędzie stosunki z Rosją. Bez względu na to, czy chodziło o politykę dynastyczną wobec Polski, politykę odprężeniową wobec Danii czy usiłowania stworzenia sojuszu z Hiszpanią, przyświecał mu zawsze ten sam cel: na różne sposoby szukać wzmocnienia dla polityki wschodniej. To tam zamierzał

7 Szerzej o tym, por. P.P. Szpaczyński, Anna I Jagiellonka kontra Jan Zamoyski. Kilka uwag w sprawie dążén królowej do zapewnienia ciagłości dynastii Jagiellonów, „Klio” 28, 2014, 1, s. 3-29. 
zbudować swoje szwedzkie imperium”. Ów badacz dodaje, iż „wielu historyków badało ambitne intencje Jana na wschodzie", podaje przy tym ich nazwiska, jednak polskich historyków wśród nich brak! Rosyjscy badacze, jak chociażby Boris N. Floria (Boris Florâ) i Rusłan G. Skrynnikow (Ruslan G. Skrynnikov), też nie mają najmniejszych wątpliwości, do czego zmierzali Jan III i Zygmunt III. Ten drugi pisze wszak wprost, że: „Jan III i jego syn zmierzali w gruncie rzeczy do rozbioru państwa rosyjskiego. Rosja niestety nie dysponowała takimi zasobami, które pozwoliłyby jej wytrzymać ciężar wojny z wrogą koalicją"9.

Przed wyborem Zygmunta na tron Rzeczypospolitej projektów tych nie osłaniano żadną tajemnicą. Wystąpienie szwedzkich posłów na sejmie elekcyjnym w 1587 r. nie pozostawiało najmniejszych złudzeń co do intencji Jana III: „Król Szwecji obiecuje, że jeśli Polacy pomogą, w co on jako wierzący wierzy, że z Bożą pomocą się stanie, to on opustoszy i rozgrabi moskiewskie ziemie, o co z miłością Boską będzie nie trudno, bo siły Moskwicina znacznie osłabły i nie będą mogły wytrzymać presji takiej koalicji"10. Konkluzja autora Zdania dyskursem wyrażonego przed wyborem Zygmunta wprost wskazywała, że będzie on panował nie tylko w Polsce i w Szwecji, ale i w Moskwie: „Nie rozumiem, jakiego by sobie Króla pożyteczniejszego miała szukać ta Rzeczpospolita chrześcijańska nad niego, który gdy dostanie Moskwy przejdzie możnością i zjednoczeniem państwa wszystkie insze Pany Europejskie"11. Po koronacji Zygmunt III wprost zapewniał papieża, że nie tylko Szwecję, ale i Moskwę nawróci na katolicyzm ${ }^{12}$. I o ile zapewnienie o nawróceniu Szwecji i Moskwy miało charakter propagandowy, to wymienienie Moskwy, której ewentualne nawrócenie mogłoby się przecież dokonać jedynie po jej podporządkowaniu, świadczyło o rzeczywistych dążeniach króla. Na sejmie wiosną 1589 r. Zygmunt III w legacji, wzywając do wypowiedzenia wojny Moskwie i uchwalenia na ten cel odpowiednich środków, określił cel konfrontacji zbrojnej jako spowodowanie, żeby „raz na zawsze otrząsnąć się tym grubym i nieprzyjaznym ludziom"13.

${ }^{8}$ L.E. Wolke, Jan III Waza. Władca renesansowy, Gdańsk 2011 (oryg. szw. 2004), s. 278.

${ }^{9}$ R.G. Skrynnikow, Borys Godunow, Warszawa 1982 (oryg. ros. 1978), s. 44.

${ }^{10}$ E. Mayer, Des Olmützer Bischofes Stanislaus Pawłowski Gesandtschaftsreisen nach Polen aus Anlass der Königswahl nach dem Ableben Stefan I. (1587-1598). Nach den handschriftlichen Quellen des k. k. geh. Haus-, Hof- und Staats-Archivs zu Wien und des Olmützer fürsterzbischöflichen Archivs zu Kremsier, Wien 1861, s. 360.

${ }^{11}$ BC, Teki Naruszewicza 92, „Zdanie dyskursem wyrażone, kto by miał być obrany królem w Polsce po zejściu Najjaśniejszego Stefana Batorego króla polskiego", 1587, s. 693.

12 BJ, rkps 1135, Legacja Zygmunta III dla S. Reszki, Kraków, 10 III 1588, k. 35ver.-36.

13 BC, rkps 1621, Instrukcja królewska na sejmiki, 23 XII 1589, s. 161-179. 
Wszystko to dowodzi, że król chciał zawojować Moskwę jeszcze zanim utracił Szwecję i przeczy „dominującej” w historiografii opinii, że Zygmunt III, prowadząc od 1609 r. wojnę na wschodzie, czynił to przede wszystkim z myślą o odzyskaniu Szwecji. Fakty te nie zostały wprawdzie przedstawione $\mathrm{w}$ monografii $\mathrm{w}$ takiej formie jak tutaj, czyli w jednolitym ciągu po sobie, można było jednak oczekiwać, iż ich rozproszenie ze względu na chronologię nie utrudni odbiorcom uchwycenia myśli przewodniej, na którą wskazują dodatkowo tytuły poszczególnych rozdziałów i podrozdziałów.

Tymczasem Opaliński konkluduje, że w książce nie udowodniono zamierzeń mocarstwowych, a raczej „przedstawiono politykę królewską jako reagującą na bieżące zagrożenia i starającą się wykorzystać pojawiające się szanse" $(0793,794)$. Otóż, po pierwsze, czym innym są mocarstwowe zamierzenia, a czym innym ich realizacja. W polskich warunkach, gdzie szlachta z posuniętymi do granic absurdu przywilejami wychodziła z nonsensownego założenia, że wojnę lepiej jest przegrać niż wygrać, król Zygmunt III mógł jedynie „reagować na bieżące zagrożenia i starać się wykorzystać pojawiające się szanse". I to niewątpliwie czynił. Bez odpowiedniej armii i opartego na stałych wpływach skarbu zrealizować swoich ambicji mocarstwowych król wprawdzie nie zdołał, ale to w żaden sposób nie może świadczyć o tym, że ich nie przejawiał.

Forsowanie przez Jana III po 1585 r. ścisłych związków z Danią nie oznaczało, wbrew temu, co stwierdza Recenzent, że król szwedzki „zmienił jednak poglądy" w kwestii połączenia Szwecji-Finlandii z Polską-Litwą celem ekspansji obu królestw w kierunku Moskwy (0779), ale było podyktowane koniecznością zabezpieczenia Szwecji od strony Danii przed ciosem w plecy, gdy do połączenia obu królestw i wspólnej ekspansji na wschodzie dojdzie. Na fakt, że niechęć Jana III w pierwszej fazie trzeciego interregnum do wysyłania syna do Polski była tylko pozorna, wskazuję w swojej książce, wbrew temu, co zarzuca mi Opaliński. Na s. 58 mamy przecież wyraźnie: „Król Szwecji Jan III, próbując jak najwięcej ugrać, sugerował, że elekcją syna w Rzeczypospolitej nie jest zainteresowany”. Recenzent zgadza się „z wywodem, że Jan III nie wierzył w wybór przez Polaków cara Fiodora, gdyby Zygmunt nie kandydował", a także z argumentacją, iż „fakt wyboru Maksymiliana na polski tron mógłby być niewygodny dla Szwecji”, formułuje przy tym jednak pytanie: „czy w Szwecji rzeczywiście wiedziano, jakie są szanse poszczególnych kandydatów?" (0779). Otóż nie ma żadnych podstaw, aby twierdzić, że Jan III nie zdawał sobie z tego sprawy, sam wszak dwukrotnie kandydował do tronu polskiego, rywalizując zarówno z kandydatem rosyjskim, jak i habsburskim. 
Bez wątpienia zdawał sobie sprawę, że przyszły król Polski musi być katolikiem i na stałe rezydować w Polsce (do tego wszak przygotowywał Zygmunta od dziecka), stąd wmawianie Janowi III przez historyków, że bał się wyboru cara Fiodora, który tych warunków sine qua non nie spełniał (a do tego jeszcze był niedorozwinięty umysłowo), jest po prostu absurdalne. Arcyksiążę Maksymilian wprawdzie był katolikiem i mógł na stałe rezydować w Polsce, jednak Jan III nie mógł nie wiedzieć o niechęci szlachty do Habsburgów, którzy już dwa razy bezskutecznie ubiegali się o tron polski, a w $1587 \mathrm{r}$. podejmowali swe starania po raz trzeci. Był też świadomy, że w czasie drugiego bezkrólewia ogłoszono królem samego cesarza Maksymiliana II i znał powody, dla których mimo to Habsburg nie został ukoronowany. Żywo wówczas interesował się wszak wyborem na króla (co należy podkreślić) swojej szwagierki Anny, którą zalecał w razie gdyby jego nie wybrano, gdyż jej panowanie miało stanowić najlepszą gwarancję na przeforsowanie w przyszłości jego syna Zygmunta (co też zresztą się stało). Jan III nie mógł również nie orientować się, że zarówno forsowanie, jak i wybór w 1587 r. syna i imiennika nieżyjącego już cesarza stanowiły skrajny przejaw awanturnictwa politycznego, o czym naocznie mogli przekonać się posłowie szwedzcy, którzy przybyli na elekcję do Polski. I co najważniejsze, Jan III wiedział, że królem Polski po śmierci Stefana I nadal formalnie pozostaje jego szwagierka Anna I, i że w związku z tym praktycznie nie ma możliwości, aby dokonano jakiegokolwiek wyboru wbrew jej woli, a jej wola była jasna. Jagiellonka wyrażała gotowość, aby usunąć się w cień i przemilczeć swoje prawa tylko pod jednym warunkiem: że w żyłach przyszłych królów Polski będzie płynąć krew Jagiellonów, zatem albo królem będzie jej siostrzeniec Zygmunt, którego, jak podkreślała, „ma za syna”, albo żoną przyszłego króla będzie młodsza siostra Zygmunta - jej siostrzenica i imienniczka ${ }^{14}$.

To właśnie dlatego Jan III wysłał do Polski nie tylko syna, ale i córkę. I to również z tego powodu, nawet gdyby Zygmunt do Polski nie przybył lub w przypadku nieuzgodnienia kwestii przynależności szwedzkiej części Estonii do Szwecji zawrócił, Jan Zamoyski, ożeniony wówczas z Gryzeldą Batorówną, nie miał żadnych szans na koronę polską. Kanclerz i hetman wielki koronny w jednej osobie po śmierci Batorego bez wątpienia najchętniej sam zostałby królem, jednak, gdy dostrzegł całkowity brak poparcia dla tego zamysłu we własnym stronnictwie, zawzięty opór wobec swojej osoby ze strony przeciwnego stronnictwa Zborowskich, a także ogromną determinację Anny I w dążeniu do zapewnienia ciągłości dynastii Jagiellonów, zmuszony był, choć z wielkimi oporami, porzucić myśl o koronie.

${ }^{14}$ O tym, wszystkim jest mowa w mojej książce na s. 57, 75. 
I choć na początku maja 1587 r. Zamoyski - jak słusznie zauważył Recenzent - rzeczywiście w liście do Mikołaja Krzysztofa Radziwiłła „oświadczył stanowczo, że nie będzie popierał kardynała Batorego, bo nie ma on żadnych szans", to było to tak samo prawdziwe jak inne równie „stanowcze" oświadczenie, że „nie myśli także o koronie dla siebie” (0787). Tymczasem myślał wówczas nie tylko o koronie dla siebie (jeszcze 15 sierpnia na cztery dni przed wyborem Zygmunta sondował swoją kandydaturę, którą zgłosił - co przecież zauważył Opaliński - „niewątpliwy zamoyszczyk" Prokop Pieniążek, 0786), ale również myślał o koronie dla kardynała Andrzeja Batorego, gdyby jemu samemu się nie udało (o czym jest mowa w monografii [S88], a czego Recenzent dziwnie nie zauważa). To z tym ostatnim przecież wiązał się chytry plan kanclerza, aby nie dopuścić do przybycia Zygmunta poprzez, po pierwsze, usunięcie z konceptu posłów szwedzkich punktu o wspólnej wojnie przeciw Moskwie i, pod drugie, przede wszystkim poprzez wymuszenie na nich przekroczenia uprawnień w postaci zgody na odstąpienie Rzeczypospolitej szwedzkiej części Estonii.

Recenzent zauważa wprawdzie, że „Wiele mówiąca była reakcja Litwinów na elekcję królewicza Zygmunta. Otóż poselstwo litewskie wysłane 22 sierpnia do senatorów koronnych oświadczyło: «obawiamy się, aby pod osobą Królewica Szwedzkiego nie dano nam jakiego Piasta albo Batorego»”, jednak dla niego jest to „oczywista aluzja do planów Zamoyskiego”, która „jest wyraźnym potwierdzeniem podejrzenia, że kanclerz myślał o koronie dla siebie" (0787)". Tymczasem po wyborze Zygmunta Zamoyski już nie myślał o koronie dla siebie, ale dla Andrzeja Batorego, czego Recenzent nadal nie zauważa, mimo że posłowie litewscy nie wymienili wprost nazwiska Zamoyskiego, a kardynała i owszem. Ba, wojewoda trocki Jan Hlebowicz 22 sierpnia przecież wprost oświadczył: „Do tego jeśliby królewicz Szwedzki dla obierania Maksymiliana tu nie chciał przyjechać, obawiam się, aby Batorego temiż ludźmi i skarbami, które chowa tamta strona dla Szwedzkiego, nie wsadzono, dawszy mu za żonę Królewnę Szwedzką"15. Poza tym nie tylko Litwini podejrzewali kanclerza o chęć przeforsowania Batorego. Ba, tego typu podejrzeń nie brakowało również w otoczeniu samego Zamoyskiego, skoro przychylny mu opat jędrzejowski Stanisław Reszka zapisał w swym diariuszu 1 października, że: „de tertio alicuius regis nova electione mussitabatur et nominabatur vel Cancellarius vel kardinalis Battoreus"16.

15 Dyjaryjusze sejmowe r. 1587. Sejmy konwokacyjny i elekcyjny, wyd. A. Skołowski, Kraków 1887, SRP, t. 11, s. 153.

16 S. Reszka, Diarium 1583-1589, wyd. J. Czubek, Kraków 1915, s. 155, 158. 
On to również pisał w swym dzienniku o potajemnych rozmowach, jakie odbywał wówczas kanclerz z kardynałem Andrzejem, którego ściągnął do Krakowa. Otóż, nie mogąc przeforsować własnej kandydatury, Zamoyski zamyślał, aby doprowadziwszy do nieprzybycia Zygmunta, przy pomocy wrogiej Habsburgom Turcji, Tatarów i Siedmiogrodu osadzić na tronie stryjecznego brata swojej żony. Skoro sam nie miał szans zostać królem, przy Batorym mógłby zachować przynajmniej pozycję wszechwładnego ministra. Przychylność stronników królewicza Zygmunta z Anną I na czele zamierzał zyskać przez spełnienie warunku sine qua non pozostającej formalnie nadal królem królowej-wdowy, a mianowicie poprzez małżeństwo Andrzeja Batorego z siostrą Jagiellona po kądzieli - Anną ${ }^{17}$. $\mathrm{Z}$ konieczności spełnienia tego warunku zdawał sobie sprawę wojewoda trocki, o czym wspomniano wyżej. Ultimatum, zmuszające elekta Zygmunta do opuszczenia kraju w momencie, gdy zjawił się w Krakowie, było dla kanclerza Zamoyskiego ostatnią szansą na zrealizowanie tego planu. O tym wszystkim jest mowa w monografii (S88) i dziwne, że Recenzent tego zupełnie nie dostrzega i w ogóle się do tego nie odnosi.

Co więcej, Opaliński pisze: „Jak się wydaje, P. Szpaczyński, po opisaniu zjazdu w Rewlu, porzuca myśl, że hetman w dalszym ciągu myślał o koronie dla siebie. Świadczyć o tym może powoływanie się przez niego na opinię Jana Dzięgielewskiego, iż kanclerz chciał narzucić Zygmuntowi III swą autorytarną radę i uczynić z niego malowanego króla" (0788). Tymczasem wydarzenia w Rewlu opisano (S122-127), przywołana opinia zaś pojawia się w zupełnie innym kontekście (S90). Kanclerz Zamoyski i owszem, nie mogąc pozbyć się króla z kraju, chciał uczynić z niego figuranta, Zygmunt III sobie na to jednak nie pozwolił.

Recenzent pisze: „Opis wysiłków dyplomacji carskiej i dyplomacji habsburskiej, które dążyły do osłabienia polskiego monarchy, a nawet w wypadku arcyksięcia Maksymiliana oraz cara Fiodora do jego detronizacji, wskazuje raczej na kroki młodego Wazy zmierzające do neutralizacji tych dążeń niż na próbę realizacji dążeń mocarstwowych" (0779). Tymczasem ja (S114-115, 348) wskazuję przecież na fakt, że Zygmunt, aby realizować dążenia mocarstwowe, musiał zacząć od zneutralizowania polityki Wiednia, aby nie dopuścić do porozumienia Habsburgów z Moskwą. Temu miało służyć m.in. właśnie mamienie Habsburgów rzekomą cesją tronu. I dodaję $(\mathrm{S} 153,349)$, że Habsburgów usiłowano zneutralizować takimi metodami, jakie znane i powszechnie używane były w szwedzkiej

17 O tym, że J. Zamoyski po elekcji Zygmunta III przygotowywał potajemnie kandydaturę A. Batorego, zob. też K. Lepszy, Walka stronnictw w pierwszych latach panowania Zygmunta III, Kraków 1929, s. 43 n. 
dyplomacji. Ba, nie tylko w szwedzkiej, bo i carska dyplomacja łudziła Habsburgów rzekomym testamentem Iwana IV, w którym car Groźny wyznaczył ich - jak przekonywano z Kremla - na swoich sukcesorów (o czym S94, 99, 115, 127, 132, 246, 349), a nawet w samej Polsce tego typu mamienia miały już swoją tradycję za czasów Zygmunta III. Przywołuję przecież (S153) obietnice składane Habsburgom przez Zygmunta II Augusta, Recenzent jednak w żaden sposób się do tego nie ustosunkowuje.

Przy charakteryzowaniu treści rozdziału pierwszego, poświęconego omówieniu literatury przedmiotu dotyczącej stosunków Rzeczypospolitej z Habsburgami, Szwecją i Moskwą, zdumienie Opalińskiego „budzi pominięcie ważnego sąsiada państwa polsko-litewskiego, jakim była Turcja" (0778). Owo zdumienie wynika zapewne z zasugerowania się przez niego tytułami rozdziału i podrozdziałów. Literatury dotyczącej stosunków Rzeczypospolitej z Turcją wszak nie pominięto, a omówiono łącznie z literaturą dotyczącą stosunków Rzeczypospolitej z Habsburgami (S21, 23-24, 27) z uwagi na wzajemne powiązania (zabiegi o ligę antyturecką, rywalizacja w księstwach naddunajskich). Turcji nie eksponowano wprawdzie w tytułach poszczególnych rozdziałów i podrozdziałów monografii, stosunki z nią zostały tam jednak omówione w powiązaniu z kwestiami szwedzkimi i moskiewskimi, które to kwestie - jak Opaliński słusznie zauważył - są w monografii „osią wywodu o mocarstwowych dążeniach Zygmunta III" (O779).

Recenzenta nie powinno dziwić, iż kwestie tureckie nie są eksponowane, gdyż w książce w kilku miejscach wyraźnie zostało wskazane (m.in. S297, 348), iż mocarstwowe dążenia króla Zygmunta III nie obejmowały Turcji. Ba (S350), że odmienna od królewskiej wizja imperializmu kanclerza Jana Zamoyskiego, wymierzonego w Turcję, była jedną z przyczyn stojących na przeszkodzie realizacji mocarstwowych zamierzeń króla. Wynikiem niezrozumienia braku eksponowania w książce kwestii tureckich na równi z pozostałymi jest również twierdzenie Recenzenta, iż „argumentacja dla przyjęcia” 1618 r. jako punktu zwrotnego w mocarstwowych dążeniach Zygmunta III (a mianowicie, że odtąd król będzie usiłował forsować swe plany w oparciu o układy z Habsburgami, wykorzystując szansę, jaką stworzy ku temu wojna trzydziestoletnia) „budzi pewne opory, gdyż podczas walk z Turcją monarcha próbował wciągnąć do działań militarnych nie tylko Habsburgów, ale i połowę Europy" (0778).

Oczywiście w pełni zgadzam się z Recenzentem, że król podejmował takie próby, tyle że to nie było częścią jego mocarstwowych zamierzeń, a palącą potrzebą chwili w obliczu niespodziewanej agresji tureckiej po klęsce pod Mohylewem, którą w czasie odwrotu z kolejnej awantury mołdawskiej Polacy zadali sobie sami swoim bezhołowiem, rozrywając 
tabor. Co do dążeń mocarstwowych Zygmunta III po 1618 r., to należy upatrywać ich w podtrzymywaniu przez królewicza Władysława pretensji do tronu carów, w nieuznawaniu za cara Michała Romanowa, w nieakceptowaniu warunków zawartego rozejmu, a nade wszystko w zabiegach Zygmunta III o odzyskanie tronu szwedzkiego, co, gdyby się ziściło, zmieniłoby w oczywisty sposób kierunek szwedzkiej ekspansji z południowego - przeciw Rzeczypospolitej - na wschodni, skierowany przeciw Moskwie, gdzie tron miał objać wybrany carem królewicz Władysław. Zygmunt III u progu wojny trzydziestoletniej wiązał wielkie nadzieje na sojusz z Habsburgami hiszpańskimi, który miał mu zapewnić realizację jego planów. Z tym łączył się też mało znany w polskiej historiografii zamysł Zygmunta III, aby rozszerzyć projekt imperium dynastycznego i w Danii osadzić na tronie młodszego syna Jana Kazimierza. Zabezpieczenie granic szwedzkich ze strony Danii i granic Rzeczypospolitej ze strony Habsburgów pozwoliłoby Zygmuntowi III na walną rozprawę z Moskwą ${ }^{18}$. Kwestii tych oczywiście nie omawiano tak szczegółowo w książce, gdyż przekraczają jej ramy chronologiczne, podkreślono jedynie, że mocarstwowe dążenia Zygmunta III nie kończą się bynajmniej w roku $1618^{19}$.

Przy omawianiu treści trzech kolejnych rozdziałów Recenzent oczekiwałby wytłumaczenia „zaskakującej - jego zdaniem - chronologii”, rozdział drugi wszak „ukazuje rolę Habsburgów w polityce królewskiej w latach 1587-1592”, podczas gdy "pozostałe rozdziały doprowadzone są do roku 1618” (0778-779). Opaliński zauważa wprawdzie, iż „w omawianym rozdziale przedstawiono także obszernie relacje polsko-szwedzkie w kontekście stosunków z Habsburgami i Moskwą" (0779), nie zauważa jednak przy tym, że ów rozdział, w przeciwieństwie do pozostałych dwóch, rozpoczyna się w roku 1587 (kolejne w 1592). Oczywiście w pełni się zgadzam z Recenzentem, że „cesarz i jego krewni odgrywali ważną rolę w planach polskiego monarchy i po 1592 r.", te kwestie zostały jednak omówione w ramach dwóch kolejnych rozdziałów - osobno w kontekście stosunków ze Szwecją w rozdziale trzecim i osobno w kontekście stosunków z Moskwą w rozdziale czwartym. Sam recenzujący książkę przecież to zauważa, gdy pisze, iż w ostatnim rozdziale poświęconym imperialnym dążeniom Zygmunta III dotyczącym Rosji w latach 15921618: „W sposób interesujący przedstawiono relacje dyplomatyczne między Moskwą a Rudolfem II. Każda ze stron miała inne interesy. O ile cesarz usiłował wciągnąć cara do ligi antytureckiej, to Fiodor proponował

18 P.P. Szpaczyński, Odpowiedź Henrykowi Wisnerowi, s. 217-218.

19 Mocarstwowe dążenia Zygmunta III po 1618 r. zostaną omówione w przygotowywanej przeze mnie biografii króla. 
przymierze antypolskie i antyszwedzkie" (0780). W tym rozdziale przedstawiono też wydarzenia wspomniane przez niego jako „ważne w planach polskiego monarchy i po 1592 r.” - „rywalizację polsko-habsburską w latach 1595-1600 w Mołdawii" oraz zawarcie tzw. paktu familijnego z Habsburgami w 1613 r. (0779). Tylko w taki sposób można było osiągnąć to, o czym informuję we wstępie monografii (S9) a mianowicie, iż „wewnątrz poszczególnych rozdziałów zastosowano głównie narrację chronologiczną, nie unikając chronologiczno-rzeczowej”.

Moje podejrzenie, a nie pewność co do tego, że król nie miał większego wpływu na warunki pokoju między Szwecją a Rosją w 1595 r. (0779) wzięło się stąd, iż układ ten zawarto przecież w imieniu Zygmunta i król ów układ zaakceptował. Książę Karol, z którego inicjatywy do zawarcia pokoju w Tiawzinie doszło, w przeciwieństwie do króla doskonale wiedział, iż ma on być wstępem do otwartej antykrólewskiej rebelii w Szwecji i wojny z Rzecząpospolitą. Zygmunt mimo wszystko w pierwszej połowie 1595 r. takiego obrotu sprawy nie mógł się spodziewać, stąd nie miał powodu, aby sprzeciwiać się rezygnacji z części południowych terenów wiernego sobie Księstwa Finlandii w zamian za korzystną dla Finów rekompensatę w postaci północnego Savo, północnej Ostrobotni i Laponii. Tymczasem wiarołomny Karol chciał w ten sposób uniemożliwić Zygmuntowi dotarcie lądem do Finlandii w czasie wojny, którą on już wówczas zaplanował.

Recenzent wskazuje, iż „Opisując wielkie poselstwo Lwa Sapiehy do Moskwy w 1600 r. i jego fiasko” stwierdzam, „że Moskwa nie chciała nawet przedłużyć rozejmu i czekała na wieści o sukcesach Michała Walecznego w walkach z Zamoyskim. Zmieniła postawę na wieść o klęsce Michała" (0781). Otóż należałoby jeszcze dodać, iż na postawę Moskwy, o czym również piszę (S266-267) wpływały przede wszystkim sukcesy Szwedów w Inflantach, a także - najpierw oczekiwanie na zdążające na Kreml poselstwo ze Szwecji, a następnie fiasko rozmów moskiewskich z posłami szwedzkimi. Prawdą jest, iż przełom w rozmowach nastąpił w momencie, gdy nadeszła wieść o klęsce Michała, tyle że nie oznacza to bynajmniej, wbrew temu, co stwierdza Opaliński, iż „tym samym” przyznaję „rację kanclerzowi, że walcząc w księstwach naddunajskich, działał jednak w imię racji stanu” i że zapomniałem „chyba o tym, iż wcześniej” obarczałem „kanclerza winą za sukcesy Szwedów w Inflantach w 1600 r.” (0781). Recenzent wcześniej sam wszak uznał, iż „Należy się w pełni zgodzić $\mathrm{z}$ opinią, że podjęta $\mathrm{w}$ drugiej połowie $1600 \mathrm{r}$. wyprawa Jana Zamoyskiego do Mołdawii i Wołoszczyzny pomogła Szwedom w opanowaniu Inflant" (0780). Trudno wobec tego nie zauważyć, że gdyby nie „pomogła”, to nie byłoby potrzeby wysyłać poselstwa do Moskwy 
z kuriozalną propozycją unii, zadecydowały o tym wszak sukcesy Szwedów w Inflantach i obawa, aby do wojny przeciw Rzeczypospolitej nie przystąpiła wówczas również Rosja.

W 1600 r. należało dokonać wyboru, czy bronić Inflant przed Szwedami, czy też przeciwdziałać wzmocnieniu pozycji księcia Michała w księstwach naddunajskich i wybór, którego wówczas dokonał Zamoyski, nie był zgodny z racją stanu Rzeczypospolitej, gdyż oczywistym było, iż należało najpierw bronić własnego terytorium. Przereklamowany w historiografii kanclerz i hetman Zamoyski nie pierwszy raz zresztą przedłożył wówczas interes własny (gdyż to jego interesom i interesom jego przyjaciela Mohyły przede wszystkim nie odpowiadało zbieżne z interesami Habsburgów wzmocnienie pozycji księcia Michała Walecznego w księstwach naddunajskich) nad interes Rzeczypospolitej, stąd nie bez przyczyny niedający się nabrać na mit „wielkiego patrioty” badacze trafnie określili jego nie pierwszą przecież w 1600 r. interwencję w księstwach naddunajskich jako awanturnictwo ${ }^{20}$.

Fakt, że rokosz utrudnił położenie Rzeczypospolitej w Inflantach, jest oczywisty. Moje twierdzenie, że bunt, który wzniecił Zebrzydowski, ,przekreślił nadzieję króla na odzyskanie tronu szwedzkiego”, nie pozostaje bynajmniej w sprzeczności z późniejszymi „kilkakrotnymi” jak zauważył Recenzent - „stwierdzeniami, że Zygmunt III prowadził w Szwecji agitację na rzecz pozbawienia tronu Gustawa Adolfa" (0780), nie oznacza wszak, że po rokoszu król wyrzekł się swoich uzasadnionych roszczeń do tronu szwedzkiego. Nie można jednak zapomnieć, iż rokosz był odpowiedzią na pakiet koniecznych do zwycięstwa w wojnie ze Szwedami reform, z którymi Zygmunt III wystąpił w nadziei, że po ich przeprowadzeniu uda się odnieść zwycięstwo w Inflantach, przenieść wojnę do Szwecji i odzyskać dziedziczną koronę. Nadzieja ta była uzasadniona tym bardziej, że na Kremlu zasiadł wówczas dzięki królewskiej przychylności Dymitr I, który deklarował wsparcie dla tego przedsięwzięcia. Rokosz bez wątpienia te nadzieje przekreślił, krzyżując królowi przede wszystkim plany reform, ale też przyśpieszając niekorzystny dla króla i Rzeczypospolitej obrót spraw w Rosji. Z tym ostatnim Recenzent zresztą się zgadza, pisząc, iż „Można się zgodzić, że wieści o zerwanym sejmie 1606 r. i o działaniach opozycji, jakie wraz z orszakiem Maryny przyszły do Moskwy, mogły przyspieszyć realizację zamierzeń bojarów” (0781).

Recenzent, wątpiąc w pytaniu: „Czy bojarzy zawiązali spisek, jak sugeruje Autor, aby uniemożliwić carowi Dymitrowi wojnę z Turcją w obawie, że ewentualny sukces wzmocni jego pozycję?" (0781) i uzasadniając

20 Z. Spieralski, Awantury mołdawskie, Warszawa 1967, s. 146 n.; S192. 
swoje wątpliwości wywodem, że „Przecież sam stwierdza, iż poselstwo moskiewskie w Rzeczypospolitej już na początku stycznia 1606 r. sondowało stanowisko polskie na wypadek obalenia cara (S282). Tak więc spisek zawiązywany był niemalże od początku jego panowania" (0781), ewidentnie się pogubił. Otóż w momencie, gdy nie „poselstwo moskiewskie w Rzeczypospolitej", jak chce Recenzent, a goniec carski Iwan Bezobrazow, i nie „na początku”, tylko w połowie stycznia 1606 r. (S282) sondował stanowisko polskie na wypadek obalenia cara, plany Dymitra I co do wojny z Turcją były już powszechnie znane. Ów goniec wszak przybył z zapowiedzią przybycia wielkich posłów, którzy mieli rozpocząć rozmowy w sprawie planowanej przez cara wojny z Turcją właśnie. Ba, o planach tej wojny króla car Dymitr I poinformował oficjalnie na kilka miesięcy zanim zaczęto sondować stanowisko polskie na wypadek jego obalenia, o czym wiemy z instrukcji dla posła carskiego z 5 września $1605 \mathrm{r}^{21}$

To prawda, że „Zygmunt III niezależnie od układu z Wyborga zdecydowałby się na wojnę" (0781-782) z Rosją, w którymś momencie jednak musiała zapaść decyzja ostateczna, od której nie było już odwrotu i zapadła ona - moim zdaniem - po zawarciu sojuszu rosyjsko-szwedzkiego w Wyborgu, skierowanego przeciw Rzeczypospolitej i oznaczającego zerwanie rozejmu polsko-rosyjskiego z roku $1608^{22}$. Nie pozostaje to bynajmniej w sprzeczności z faktem, że król o wojnie z Rosją myślał znacznie wcześniej. Autor artykułu recenzyjnego twierdzi, że dopiero od listopada 1608 r. (0781) - ja, że od początku swojego panowania. Faktem jest przecież, że Zygmunt III wojnę z Rosją proponował już na sejmie pacyfikacyjnym w 1589 r. W Zwierciadle Rzeczypospolitej z 1598 r. w odpowiedzi na zarzuty opozycji wobec króla, że „dział ze Szwecji obiecanych nie oddał” czytamy, iż „do dobywania Nowogrodu, Pskowa i Smoleńska, do których te działa obiecane są, jeszcze nie przyszło"23. W instrukcji na sejm w 1600 r. Zygmunt III pisał w odniesieniu do cara, żeby: „albo o wojnie z nim albo o pokoju na sejmie postanowić” ${ }^{24}$, choć

${ }^{21}$ Poselstwo, raczej instrukcja w. kniazia moskiewskiego Dymitra Iwanowicza, 5 IX 1605, w: Poselstwo od Zygmunta III, króla polskiego, do Dymitra Iwanowicza, cara moskiewskiego (Samozwańca) z okazyi jego zaślubin z Maryną Mniszchówna, oprac. J. Byliński, Wrocław 2002 , s. 149.

${ }^{22}$ O tym, że „ostateczna decyzja zapadła w końcu marca”, J. Byliński, Sejm z roku 1611, Wrocław 1970, s. 17.

${ }^{23}$ Zwierciadło Rzeczypospolitej Polskiej na początku roku 1598 wystawione, wyd. K.J. Turowski, Kraków 1859, s. 7.

${ }^{24}$ Legacja dana ks. Andrzejowi Opalińskiemu, proboszczowi płockiemu, posłowi królewskiemu na sejmik przedsejmowy w Środzie, 12 I 1600, Akta sejmikowe województw poznańskiego i kaliskiego, wyd. W. Dworzaczek, t. 1: 1572-1632, cz. 1: 1572-1616, Poznań 1957, s. 215. 
oczywistą kwestią było, że pokój bez wojny nie był możliwy, bo Rosja Smoleńska dobrowolnie nie zwróci, czyli warunku sine qua non pokoju nie spełni. Stąd Recenzenta nie powinny dziwić słowa, że: „Genezy wojny państwa polsko-litewskiego z Rosją w latach 1609-1618 należy upatrywać w mocarstwowych dążeniach Zygmunta III, który od początku swego panowania w Rzeczypospolitej dążył do walnej rozprawy z Rosją" (0781).

Gdy jednak Recenzent pisze: „Ponadto stwierdzono, że kwestią sporną jest, do czego dążył monarcha, rozpoczynając wojnę z Moskwą w 1609 r." i dodaje, że: „Nie jest to naszym zdaniem słuszna teza. Warto przy tym zauważyć, że Zygmunt III nie odstąpił od oblężenia Smoleńska, i zapewne taki był plan pierwotny albo plan minimum, jak chce Henryk Wisner" (0781), to nie zauważa, iż moje stwierdzenie, że „kwestią sporną jest, do czego dążył monarcha, rozpoczynając wojnę z Moskwą w 1609 r." kończy się przypisem (przyp. 329, rozdz. 4), w którym jest wyraźnie mowa o tym, że ów spór odnosi się do historiografii, gdzie dominuje stanowisko, iż król miał dwa plany - maksymalny i minimalny, i ten drugi zakładał odzyskanie awulsów, a ten pierwszy zdobycie korony carów - według jednych badaczy dla siebie, a według innych dla syna. W mojej ocenie Zygmunt III chciał wówczas, aby carem został Władysław, z tym że dla siebie oczekiwał czasowej regencji do momentu, aż królewicz osiągnie pełnoletniość i na tyle ugruntowaną pozycję, aby jego życiu i panowaniu na Kremlu nic nie zagrażało. Awulsy na czele ze Smoleńskiem miały zaś, co oczywiste, powrócić do Rzeczypospolitej, gdyż ich odzyskanie od ponad stu lat stanowiło warunek sine qua non pokoju z Rosją.

Nigdzie w książce nie twierdzę, że sejmiki deputackie w 1609 r. „,nie poparły wojny z Moskwą" ani też, że nie uchwaliły podatków na wojnę (0782). Postawę sejmiku w Wiszni przedstawiłem jako wyjątkową, jeśli chodzi o przekonanie szlachty, że wierzy w zapewnienia króla, zawarte w deklaracjach w Wilnie i Lublinie, iż wyruszając na wojnę kieruje się on jedynie dobrem Rzeczypospolitej. W laudum sejmiku wiszeńskiego czytamy wszak: „my tedy nie mogąc tej wdzięczności w sobie taić, naprzód J. Kr. Mci p. n. m. za te wszystkie prace i starania, które dla Ojczyzny naszej podejmować raczy uniżenie dziękujemy, życząc tego wiernie, aby Pan Bóg J. Kr. Mć. w dobrym zdrowiu z Sławnem zwycięstwem do nas przeprowadzić raczył" 25 .

Tajnych rokowań z Habsburgami nie podjęto „wkrótce po odwiedzinach króla u arcyksięcia Maksymiliana w Krasnymstawie (18 IV 1589)" (0783), ale tuż przed tymi odwiedzinami. Zygmunt III do Krasnegostawu przybył wszak 28 maja, a nie 18 kwietnia, rokowania zaś podjęto dzień

${ }^{25}$ Laudum sejmiku wiszeńskiego, Wisznia, 14 IX 1609, w: AGZ, t. 20, s. 130. 
wcześniej 27 maja. W monografii rzeczywiście najpierw omówiono ratyfikację układu bytomsko-będzińskiego przez króla (co miało miejsce 18 IV 1589 r. w Warszawie), następnie zaś jego uroczyste zaprzysiężenie, którego król dokonał w obecności cesarskiego posła w Lublinie (24 maja) a w końcu odwiedziny w Krasnymstawie (28 maja), dokąd Zygmunt III udał się z Lublina. Dopiero później przedstawiono zainicjowane dzień wcześniej tajne rokowania, gdyż ta ostania kwestia wymagała już dłuższego wywodu. Wobec tego nie ma się co dziwić, że „nie wskazuję na związek" (0783) między wizytą króla a początkiem tajnych rokowań, gdyż związku takiego nie było.

Opaliński twierdzi, że argument, iż „niechęć, a nawet wrogość kanclerza również nie mogły skłaniać króla do rezygnacji z tronu polskiego, ponieważ przenosząc się na stałe do Szwecji i nie zmieniając wyznania, miałby te same, jeśli nie większe problemy ze stryjem Karolem, fanatycznym luteraninem, wykorzystującym religię do walki z bratankiem" „nie jest tak jednoznaczny” jak pozostałe, gdyż Zygmunt „miałby wówczas szansę na pilnowanie własnych spraw osobiście” (0783). Tyle że nie wydaje się, aby Zygmunt kiedykolwiek chciał skorzystać z tej szansy. Dlaczego miałby tego chcieć w 1589 r. (gdy nie było w zasadzie takiej potrzeby, gdyż jego spraw pilnował wówczas ojciec), skoro nie chciał tego później - ani bezpośrednio po śmierci Jana III na przełomie lat 1593 i 1594, ani podczas wyprawy w 1598 r., gdy przebywał w Szwecji i gdy potrzeba była oczywista?

Za każdym razem Zygmunt tę szansę „na pilnowanie własnych spraw osobiście" odrzucał, wracając do Polski. Dlaczego? Otóż dlatego, że Zygmunt bez korony Jagiellonów nie wyobrażał sobie swojego panowania w królestwie dziedzicznym. Został wszak wychowany przede wszystkim na króla Polski, tym też zresztą był uzasadniany w Szwecji jego katolicyzm. Wychowany na króla Polski zaś został po to, aby połączyć pod swym berłem oba królestwa przeciw Moskwie, co było idée fixe życia jego ojca, a z czasem stało się i jego samego. Rezygnacja z tronu polskiego była niemożliwa, musiałaby wszak pociągnąć za sobą nie tylko zmianę wyznania Zygmunta, ale przede wszystkim wojnę z Rzecząpospolitą, gdyż to byłby wówczas jedyny możliwy kierunek szwedzkiej ekspansji, koniecznej dla modernizacji państwa. Tymczasem ów południowy kierunek był sprzeczny z dążeniami króla i celami, wpajanymi mu przez Jana III od dziecka, co do których Zygmunt był przekonany, iż stanowią one rację stanu obu królestw, a za ich przyszłość on, jako potomek dwóch dynastii, czuł się odpowiedzialny.

Stąd monarcha, postawiony przed koniecznością dokonania wyboru między królestwami, wolał utracić przejściowo Szwecję, wierząc, że 
z czasem ją odzyska - prawa dziedziczne były wszak niezbywalne niż zrezygnować z dziedzictwa Jagiellonów i wyrzec się swych dążeń mocarstwowych. Gdy korona dziedziczna wymykała się Zygmuntowi z rąk, monarcha, budujący od kilku lat własne stronnictwo w Rzeczypospolitej, nie tracił nadziei, że uda mu się w przyszłości nawet bez Szwecji doprowadzić do zrealizowania imperialnych dążeń wobec pogrążającej się coraz bardziej we wszechogarniającym chaosie Moskwy. Odzyskanie królestwa dziedzicznego zaś pozostanie już wówczas niejako konsekwencją osiągniętego celu na wschodzie (S350-351).

Recenzent twierdzi, że w kwestii cesji tronu „wywody niewątpliwie podważyły w pewnym stopniu dotychczasowe stanowisko historiografii, ale go nie obaliły, ponieważ hipoteza "gry dyplomatycznej», aczkolwiek atrakcyjna, jest nie do udowodnienia, opiera się bowiem na hipotetycznym założeniu, że dla Zygmunta III wszystko od początku było świadomie podjętą grą pozorów. Jednak co monarcha myślał naprawdę w maju 1589 r., nie wiemy i zapewne nigdy się nie dowiemy" (0785). Otóż po pierwsze, z całą mocą należy podkreślić, że „owo dotychczasowe stanowisko historiografii" jest niczym innym jak wynikiem uprzedzeń polskich historyków wobec Zygmunta III, którzy zarzuty wobec króla - jak trafnie zauważył swego czasu Eugeniusz Barwiński, tłumacząc genezę negatywnego wizerunku króla w historiografii - przepisywali bezrefleksyjnie jeden od drugiego ${ }^{26}$. Austriacki badacz Walter Leitsch, który zgodził się z Barwińskim, wprost stwierdził, że ,jako student czytając publikacje polskich historyków” został „zarażony negatywnym stosunkiem do Zygmunta III” i niewątpliwie słusznie zauważył, iż „żadna postać historyczna, nie została tak niesprawiedliwie, wręcz źle potraktowana, jak właśnie ten król"27. Rosyjska propaganda w okresie zaborów i PRL-u zrobiła swoje.

Doprawdy trudno zrozumieć, dlaczego badacze tak zawzięcie wierzą, że Zygmunt III rzeczywiście chciał się zrzec tronu na rzecz arcyksięcia Ernesta, a nie wierzą, że Zygmunt II August chciał tegoż Ernesta adoptować czy że chciał odstąpić cesarzowi tron polski za roczną pensję. Dlaczego nie wierzą w zwierzenia wuja Zygmunta III, które czynił pozostającemu w bliskich stosunkach Wiedniem nuncjuszowi w $1570 \mathrm{r}$., a mianowicie, że myśli o abdykacji i chce podjąć w związku z tym za zgodą papieża rokowania z cesarzem o utworzeniu tytułu księcia Etrurii, który miałby mu przysługiwać po rezygnacji z tronu polskiego? Dlaczego wreszcie nie wierzą, że Iwan IV pozostawił testament, w którym

${ }^{26}$ E. Barwiński, Zygmunt III i dysydenci, „Reformacja w Polsce” 1, 1921, s. 51-52.

${ }^{27}$ W. Leitsch, Das Leben am Hof König Sigismunds III. von Polen, t. 1, Wien-Kraków 2009, s. 676; P.P. Szpaczyński, Spór o Zygmunta III, KH 118, 2011, 4, s. 726-727. 
Habsburgów wyznaczył na swoich następców? I dlaczego w związku z tym Zygmunt II August mógł łudzić Habsburgów następstwem w Polsce, Kreml mógł łudzić Habsburgów następstwem w Moskwie, a Zygmunt III podobnie czynić nie mógł? Tym bardziej że wnuk wnuka Jagiełły miał znacznie więcej powodów, aby intrygować i w monografii w kilku miejscach (m.in. S114-115, 130, 349) skrupulatnie je wyliczyłem.

Intrygi tego typu należały do kanonu ówczesnej dyplomacji i naprawdę trudno zrozumieć, dlaczego Zygmunt III nie miał prawa z nich nie korzystać. To, że Zamoyski z królewskiego bluffu dyplomatycznego zrobił aferę, wmawiając szlachcie (podobnie zresztą jak jego następcy w czasie rokoszu), że król handluje koroną (i że zarzut ten - jak słusznie zauważył Jan Dzięgielewski, mimo iż „nigdy nie został królowi udowodniony”, to „wciąż jednak chętnie jest przez historyków powtarzany, bardziej chyba z sympatii dla Zamoyskiego niż w oparciu o rzetelne dowody, bądź racjonalne argumenty" ${ }^{28}$ ), nie może stanowić w żadnym razie o jakiejkolwiek winie monarchy. Historyków, którzy tak chętnie bezceremonialnie oskarżali króla o fanatyzm nie przekonywał i nadal nie przekonuje nawet fakt (na który wskazuję, S150), iż Zygmunt III w testamencie, który wyklucza kłamstwa, wprost zapewniał w odniesieniu do swoich rzekomych zamiarów abdykacji i cesji: „Wieści te bez żadnego fundamentu rozsiane niczym dowiedzionymi być nie mogły, jak to już wszystkim jest wiadomo” i dodawał: „by i tym, co po nas żyć będą świadomym było Boga samego bierzemy na świadka jakośmy z kimkolwiek jawnie, ni skrycie o zamiarze królestwa tego nastawali"29. Król opierał się tu niewątpliwie na fakcie, iż bluff dyplomatyczny nie był rzeczywistym zamiarem. Stąd jedyny przykład, jaki podaje Recenzent na uzasadnienie swojego zarzutu, iż „Autor posunął się do skrajnej idealizacji swego bohatera” poprzez to, iż „starał się zdjać z barków Zygmunta III jakąkolwiek odpowiedzialność za hazardową grę z Habsburgami" (0793-794), wydaje się zupełnie nietrafiony. Wcześniej Opaliński pisze, że „momentami monografia sprawia wrażenie hagiografii" (0778), szkoda tylko, że nie wskazuje żadnego z tych momentów, nie podaje żadnego przykładu, co praktycznie uniemożliwia polemikę i sprawia, iż zarzut imputujący brak obiektywizmu staje się w tym przypadku całkowicie gołosłowny.

Skoro według Opalińskiego możemy się dowiedzieć, co myślał kanclerz Zamoyski, który „nie pozostawił żadnych śladów w źródłach na poparcie przypuszczenia, że myślał o koronie dla siebie” i że „w związku z tym”, jak przekonuje, nie ,jesteśmy skazani jedynie na domysły, których nie

${ }^{28}$ J. Dzięgielewski, Sejmy elekcyjne, elektorzy, elekcje 1573-1674, Pułtusk 2003, s. 177.

${ }^{29}$ J.U. Niemcewicz, Dzieje panowania Zygmunta III, t. 3, Kraków 1860, s. 347. 
sposób udowodnić”, gdyż „wydaje się, że można spróbować połączyć ze sobą poszczególne działania Zamoyskiego, w celu uchwycenia wspólnej dla nich myśli przewodniej. Istnieją poza tym pośrednie przesłanki źródłowe" (0787), to dlaczego inną miarę mielibyśmy stosować do króla i twierdzić, jak to czyni Recenzent, iż „nie wiemy, co rzeczywiście myślał młody monarcha, gdy wdał się w intrygę dyplomatyczną z Habsburgami i zapewne nigdy się nie dowiemy" (0783). W kwestii tajnych rokowań, dowodząc, iż była to intryga dyplomatyczna, postąpiliśmy dokładnie w ten sam sposób - połączyliśmy ze sobą poszczególne fakty w celu uchwycenia wspólnej dla nich myśli przewodniej. I tu również „istnieją pośrednie przesłanki źródłowe”. Źródłowo jest wszak dowiedzione, że Habsburgowie ociągali się z ratyfikacją i zaprzysiężeniem układu, naciskali na Jana III, zmawiali się z Moskwą itd. Nie może być w związku z tym wątpliwości, że król miał powody, aby temu przeciwdziałać, a intryga była powszechnie znanym i stosowanym wówczas do tego narzędziem. I co najważniejsze, Zygmunt III wszystkie cele związane z intrygą osiągnął. Po wszczęciu rokowań wszak niczym za dotknięciem czarodziejskiej różdżki Habsburgowie od razu przestali ociągać się z ratyfikacją i zaprzysiężeniem układu, zaprzestali nacisków na Jana III, zaprzestali knowań z Moskwą i wspierania pretensji arcyksięcia Maksymiliana do tronu polskiego.

Gdy Opaliński snuje wywód: „Król aż do zjazdu w Rewlu (wrzesień 1589) obstawał przy pierwotnych planach matrymonialnych. W związku z tym w maju 1589 r. mógł uważać małżeństwo z luteranką za korzystne. A to z kolei nie wyklucza świadomego w tym czasie zamiaru abdykacji” (0784), to zdaje się zapominać, iż Zygmunt został zaręczony z luterańską księżniczką Holsztynu jako szwedzki dynasta zanim przybył do Polski i bez zgody ojca sam nie mógł zdecydować o zerwaniu zaręczyn. Dlatego w maju - w drodze do Rewla, gdzie Jan III po otrzymaniu oficjalnego pisma senatorów Rzeczypospolitej miał wyrazić zgodę na zerwanie przez syna zaręczyn z luteranką, Zygmunt III siłą rzeczy musiał obstawać przy pierwotnych planach. Nie protestował jednak, gdy wszyscy niemal senatorowie poparli na sejmie pacyfikacyjnym jego małżeństwo z Habsburżanką i przygotowali w tej sprawie stosowne pismo do Jana III.

Król szwedzki również bez najmniejszego sprzeciwu zgody udzielił, co poświadcza intrygę, a nie rzeczywisty zamiar abdykacji. Owa zgoda wszak na zerwanie korzystnego dla dynasty, bo wzmacniającego jego pozycję wobec protestanckiej opozycji związku z Domem Holstein-Gottorp na rzecz osłabiającej pozycję dynasty w dziedzicznym królestwie katoliczki z Domu Habsburskiego na pewno nie mogła sprzyjać zamiarom abdykacji. Z tym ostatnim Recenzent się zgadza, pisząc, iż „Realizacja 
tego pomysłu podważała z kolei sens abdykacji z tronu polskiego, gdyż osłabiała pozycję Zygmunta III w Szwecji" (0786). Co najmniej dziwne wydaje się jednak przypuszczenie Opalińskiego, że: „Może więc od tego momentu rokowania prowadzone $\mathrm{z}$ Habsburgami były jedynie zasłoną dymną dla celu realnego, to znaczy zgody cesarza na małżeństwo młodego Wazy z arcyksiężniczką austriacką" (0786).

Dziwne, gdyż Rudolf II takiemu małżeństwu po wyborze Zygmunta na tron Jagiellonów nigdy się nie sprzeciwiał, wręcz tego oczekiwał. Nie sposób więc przyjąć, że rokowania podjęto w tym celu. Uznanie zaś, że cel rozmów zmieniał się z miesiąca na miesiąc, byłoby równie absurdalne. Rozmowy wszak dopiero co zainicjowano, Habsburgom przedstawiono jedynie propozycję i warunki. Od maja do września upłynęło wprawdzie pięć miesięcy, jednak wówczas tyle czasu król musiał przeznaczyć na swoją podróż do Rewla, korespondencję w sprawie rokowań zaś zdołano wymienić zaledwie dwa, trzy razy.

Poza tym nie tylko postawa króla szwedzkiego wobec małżeństwa Zygmunta dowodzi ewidentnie intrygi, a nie rzeczywistego zamiaru abdykacji, ale również jego zawzięty upór w kwestii wyjazdu syna do Sztokholmu, o czym jest mowa w monografii (S126), a czego Recenzent nie zauważa. Zygmunt III bez zgody ojca nie mógł wszak nie tylko zerwać zaręczyn, ale też podjąć tajnych rokowań z Habsburgami w sprawie cesji, gdyby rzeczywiście chciał abdykować, a to z kolei musiałoby wpłynąć na określoną postawę Jana III w Rewlu. Tymczasem tak się nie stało, co więcej, król szwedzki w czasie kongresu w estońskiej twierdzy zachowywał się tak, jak gdyby o rokowaniach nic nie wiedział. Wiedział jednak na pewno (bo ani Zygmunt, ani tym bardziej Szwedzi z jego otoczenia nie odważyliby się intrygować za plecami Jana III), nie traktował jednak owych rokowań poważnie, gdyż stanowiły bluff dyplomatyczny.

Gdy Recenzent pisze, że:

Analiza treści traktatu świadczy jednoznacznie, że przynajmniej we wrześniu 1590 r., a więc w czasie, gdy propozycje królewskie skrystalizowały się w postaci ostatecznego projektu, monarcha nie zamierzał rezygnować z polskiego tronu. Warunki bowiem, jakie postawił, były nie do zaakceptowania przez polski parlament. Trudno sobie wyobrazić, aby sejm nie tylko zaaprobował abdykację Zygmunta III, ale jeszcze wyraził zgodę na, w praktyce, elekcję vivente rege! Również warunki postawione Ernestowi były niewykonalne" (0784-785)

to zdaje się nie zauważać, iż te warunki nie pojawiły się dopiero we wrześniu 1590 r., ale były doskonale znane Habsburgom już od końca sierpnia 1589 r. Pierwszy list króla inicjujący rokowania przygotowano 
27 maja 1589 r., arcyksiążę Ernest odpowiedział nań 28 czerwca z prośbą o podanie warunków. Odpowiedź Lambert Wrader (ten sam, który zawiózł list inicjujący rokowania, notabene zaufany Anny I Jagiellonki, który po śmierci Batorego z jej polecenia jako pierwszy udał się do Szwecji z zaproszeniem Zygmunta na tron polski) przywiózł do Wilna 10 sierpnia, a pod koniec sierpnia przedstawił Habsburgom warunki Zygmunta III, o czym jest mowa w monografii (S117-118) wraz ze wskazaniem, iż nierealność warunków ewidentnie świadczy o intrydze, a nie rzeczywistym dążeniu króla do rezygnacji z dziedzictwa Jagiellonów. Na ową nierealność ponownie wskazano przy omawianiu układu w ostatecznej formie (S152).

Stąd też Habsburgowie od samego początku mieli wątpliwości, a nawet wprost podejrzewali intrygę, jednak mimo wszystko postanowili kontynuować rokowania. Nic dziwnego, że później mieli prawo czuć się oszukani, gdy Zygmunt III po podpisaniu gotowego już układu przez arcyksięcia Ernesta swojego podpisu nie złożył i przez następne półtora roku zachowywał się tak, jak gdyby nigdy niczego Habsburgom nie proponował i niczego z nimi nie uzgadniał. Stąd mój wywód, że ujawnienie tajnych rokowań oficjalnie z woli arcyksięcia Maksymiliana, bo przez jego agenta, w rzeczywistości stanowiło zemstę Habsburgów, którzy (z jednej strony zniecierpliwieni, a drugiej rozczarowani postawą króla) chcieli tym samym wymusić niejako na Zygmuncie III dalsze kroniki i w jakiś sposób pchnać do przodu sprawę, która utknęła w martwym punkcie. Tymczasem Recenzent twierdzi, że:

Trudno się z tym wywodem zgodzić. Gdyby tak było, to oznaczałoby, że Habsburgowie chcą narażać swego powinowatego (wówczas narzeczonego arcyksiężniczki Anny) na detronizację w Polsce. Trzeba zatem przyznać rację raczej W. Leitschowi, że była to osobista zemsta niezbyt roztropnego Maksymiliana, który ponadto liczył na objęcie tronu w Krakowie po detronizacji Zygmunta III. O tym, że nie chodziło w tym wypadku o zemstę Habsburgów, przekonuje dodatkowo przytoczony przez Autora fakt, iż na prośbę króla cesarz wstrzymał wysłanie kolejnego agenta Maksymiliana do Polski (0785).

Otóż, po pierwsze, to „Habsburgowie nie mieliby żadnych skrupułów, narażając powinowatego na detronizację", gdyby tylko po owej detronizacji ich przedstawiciel zasiadł na polskim tronie. Oni wręcz życzyli Zygmuntowi III tej detronizacji, ciągle przecież mieli nadzieję, że z uwagi na problemy w dziedzicznym królestwie monarcha wyjedzie do Szwecji i do Polski już nie wróci, a wtedy oni nadal będą w grze. W tym celu nie zawahali się nawet później wprost podburzać Szwedów przeciw królowi. Co do opinii Leitscha, to należy niestety zauważyć, iż austriacki badacz nie był zbyt obiektywny, jeśli chodzi o dynastię Habsburgów, dlatego też 
wolał za wszystko obarczyć „nieroztropnego” Maksymiliana, tyle że nie sposób uwierzyć, aby ten bez zgody cesarza i pozostałych arcyksiążąt ujawniał tajne rokowania, które prowadził przecież nie on, a jego młodszy brat Ernest. W rokowaniach tych uczestniczył sam cesarz i pozostali arcyksiążęta, z którymi wszystko konsultowano. Byłoby to działanie nie tylko na szkodę „powinowatego" domu habsburskiego, ale na szkodę całej dynastii Habsburgów. Rudolf II oczywiście nie chciał, aby to wyglądało na jawną zemstę, dlatego po tym, gdy z wyrzutami u cesarskiego dyplomaty i biskupa Wrocławia Andreasa Jerina zjawił się sekretarz królewski Niklas Rask, cesarz, manifestując dobrą wolę, powstrzymał kolejnego agenta Maksymiliana. Nie świadczy to jednak o tym, że „nie chodziło w tym wypadku o zemstę", jak chce Recenzent, ale wręcz przeciwnie - o tym, że Rudolf II kontrolował całą sytuację, że miał na to wszystko wpływ, a tym samym od początku o wszystkim wiedział. Trzeba też pamiętać, że Habsburgowie z cesarzem na czele nigdy nie odcięli się od owych rzekomo „nieroztropnych” działań arcyksięcia Maksymiliana, ba, nawet nie udawali zaskoczonych ową „nieroztropnością”.

Arcyksiążę Maksymilian nieustannie starał się przekonać pozostałych Habsburgów, że oferta przedstawiona przez Zygmunta III Ernestowi jest dyplomatyczną intrygą. Tego samego zdania byli zresztą arcyksiążę Ferdynand i król Hiszpanii i Portugalii Filip II, który miał wcześniej doświadczenia ze szwedzką dyplomacją, o czym jest mowa w książce (S116, 145, 154). Co najmniej dziwna postawa Zygmunta III po wypracowaniu układu w ostatecznej formie wskazywała jednoznacznie na intrygę i Habsburgowie, ujawniając treść tajnych rokowań, niewątpliwie chcieli się przekonać, czy rzeczywiście był to tylko bluff dyplomatyczny, jak twierdzili niektórzy z nich - arcyksiążę Maksymilian, Ferdynand i Filip II. Po rozpętaniu afery abdykacyjnej, 1 września 1592 r. Jan Drucker w liście do arcyksięcia Maksymiliana, zdając mu relację, wskazywał na słowa marszałka wielkiego koronnego Andrzeja Opalińskiego skierowane do maksymilianisty, kasztelana przemęckiego Piotra Choińskiego, które potwierdzały wcześniejsze przypuszczenia niektórych członków domu cesarskiego: że Zygmunt III, obiecując następstwo Ernestowi, bluffował. Marszałek wszak wprost stwierdził, iż „bardzo się dziwi”, że „taki rozsądny Ernest” i inni „sobie nadzieję królestwa wmówić dali”, że „czuli, iż mogą tak tanim kosztem chwycić niemożliwe" ${ }^{30}$. Wiara w cesję tronu była wszak absurdalna.

${ }^{30}$ J. Drucker do arc. Maksymiliana, Neustadt, 1 IX 1592, w: J. Macůrek, Dozvuky polského bezkráloví z roku 1587. Příspěvek k osvětnení snah rodu habsburského o získání koruny polské v letech 1588-94, Praha 1929, s. 172-175; S148. 
Opaliński myli się twierdząc, że agent arcyksięcia Maksymiliana, Jan Ducker, na zjeździe w Lublinie „na polecenie swego mocodawcy wyjawił publicznie rokowania Zygmunta III z arcyksięciem Ernestem" (O789), gdyż stało się to dopiero na zjeździe w Jędrzejowie ${ }^{31}$. W Lublinie Drucker miał polecone, aby niczego nie ujawniać publicznie, a jedynie nieoficjalnie poinformować o treści tajnych rokowań niektórych senatorów, w tym Zamoyskiego. Habsburgowie chcieli najwyraźniej zobaczyć, jak Zygmunt III zareaguje na próby ujawnienia treści tajnych rokowań, gdyż dopiero gdy król wszystkiego się wyparł, polecili Druckerowi ujawnić całą sprawę w Jędrzejowie. I to dlatego właśnie „nie zauważyłem”, żeby użyć słów Recenzenta, obecności Duckera w Lublinie, a „dopiero” w Jędrzejowie (0789-790).

Recenzent nie do końca zrozumiał, o jakiej niewierze kanclerza Zamoyskiego w plany abdykacyjne króla jest mowa w monografii przy okazji wyprawy króla do Rewla. Otóż kanclerz Zamoyski nie wierzył nigdy w plany abdykacyjne króla z powodu problemów w szwedzkim królestwie, ale długo (do afery, którą rozpętał po ujawnieniu tajnych rokowań, a więc również w czasie sejmu wiosennego w 1590 r.) miał nadzieję, że z czasem uda mu się wymusić na Zygmuncie III abdykację poprzez obrzydzanie mu panowania w Rzeczypospolitej. Po ujawnieniu tajnych rokowań wierzył już nawet, że spowoduje detronizację króla, dlatego też cały czas liczył się z bezkrólewiem i na tę okoliczność się przygotowywał.

To w związku z tym właśnie w momencie, gdy Zygmunt III przebywał w Rewlu, Zamoyski, choć wątpił w pogłoski o rzekomo zaplanowanej ucieczce króla do Szwecji, nie tracił czasu, aby zniechęcać szlachtę do młodego monarchy. Temu miało służyć wyolbrzymianie przez kanclerza $\mathrm{i}$ hetmana w jednej osobie zagrożenia tureckiego i natarczywe w związku z tym wezwania króla do zawrócenia z drogi, a następnie, gdy już przybył do Rewla, do natychmiastowego powrotu. Doskonale wiedząc, że Zygmunt III ani zawrócić z drogi, ani pospiesznie wrócić z estońskiej twierdzy nie może, Zamoyski wykorzystywał okazję, aby w demagogiczny sposób przekonywać szlachtę, że na królu w razie potrzeby polegać nie można, że bardziej liczy się dla niego królestwo dziedziczne. Podsycał też swoim działaniem rozpowszechniane przez maksymilianistów pogłoski o ucieczce króla, w które - jak wspomniano - sam nie wierzył, wprost wskazując, że są dziełem habsburskich agentów (S121).

Po powrocie Zygmunta III na sejmie wiosennym w 1590 r. Zamoyski kontynuował swoją strategię, podnosząc tym razem $\mathrm{w}$ równie

${ }^{31}$ K. Lepszy, Rzeczpospolita Polska w dobie sejmu inkwizycyjnego 1589-1592, Kraków 1939, s. 346-347. 
demagogiczny sposób kwestię „praktyk rakuskich”, o których „doszły go słuchy”, dodając, że w nie wierzy. To dlatego król oficjalnie zaprzeczył, jakoby brał w tego typu praktykach udział i oświadczył, że z Habsburgami pertraktowano jedynie w sprawach matrymonialnych. Co więcej, władca (w ocenie zdecydowanej większości badaczy, jeśli już nie „fanatyk”, to na pewno „gorliwy katolik”) wzywał wówczas Boga na świadka, że jego oświadczenie jest prawdziwe. I było prawdziwe, bo tronu nigdy zrzec się nie zamierzał. Zamoyski również - jak słusznie zauważył Recenzent - poczuł się zmuszony do zdementowania pogłosek na swój temat, wyolbrzymianie wszak przezeń niebezpieczeństwa tureckiego w czasie wyprawy króla do Rewla, korelujące z pogłoskami o rzekomych zamiarach ucieczki do Szwecji, wywołało bowiem wśród jego przeciwników podejrzenia, iż w razie nowej elekcji hetman zechce przy pomocy wojsk zebranych pod pretekstem zagrożenia tureckiego przeforsować kandydaturę własną bądź (czego już niestety nie zauważa Recenzent) jednego ze swoich krewnych Batorych.

Owe pogłoski nasiliły się w 1590 r. i to nie bez przyczyny, bo to właśnie w tym roku rozpoczęły się trwające ponad trzy lata tajne rokowania kanclerza Zamoyskiego z Zygmuntem I Batorym (bratem jego zmarłej w czasie sejmu w marcu 1590 r. żony Gryzeldy), a pośrednio i z popierającą Batorych Turcją w sprawie polskiego tronu. Owe rokowania toczyły się niemal w tym samym czasie co królewskie i mimo iż trwały znacznie dłużej i że w przeciwieństwie do Zygmunta III Zamoyski, obiecując potajemnie polską koronę swojemu kandydatowi, nie bluffował, to nikt dziś o nich nie wspomina. Opaliński do tego faktu, mimo iż jest on przedstawiany w kilku miejscach w monografii (m.in. S149-150, 162-163), w ogóle się nie odnosi. Stwierdzenie Recenzenta, że „Przez niemal cały rok 1591 Zamoyski zachowuje się poprawnie wobec Zygmunta III” (0789), w kontekście tajnych rokowań kanclerza z Batorym wydaje się dość kuriozalne.

Podobnie jest z wywodem Opalińskiego, że „Zamoyski porozumiał się z maksymilianistami, których przywódca M. Kazimierski zgodził się na każdego Piasta zaproponowanego przez hetmana. Trudno przypuszczać, że kanclerz nie myślał wówczas o sobie" (0789). Kanclerz nie myślał wszak wówczas o sobie, a o swoim szwagrze Zygmuncie I Batorym (z którym przecież w tym czasie prowadził rokowania) i z zamysłu tego nie zrezygnował nawet po swojej porażce na sejmie inkwizycyjnym (do której przyczyniło się zresztą również m.in. odkrycie porozumienia Zamoyskiego z Batorym, o czym jest mowa, S149) i po wyjeździe Zygmunta III na koronację do Szwecji, kiedy to ściągnął Batorego w przebraniu na Wawel (S162-163).

Kanclerz dopiero po śmierci Jana III na krótko uchwycił się myśli, że Zygmunt III z dziedzicznego królestwa do Polski może już nie wróci. 
Dlatego nie sprzeciwiał się wyjazdowi króla do Szwecji na sejmie w 1593 r., czynił wszystko, aby ten jak najszybciej bez żadnych przeszkód w postaci jakichkolwiek deklaracji dotyczących inkorporacji Estonii Rzeczpospolitą opuścił, czym nawet wzbudził podejrzenia m.in. u prymasa Stanisława Karnkowskiego, że monarcha rzeczywiście już nie wróci ${ }^{32}$. Zapewnienia o powrocie, jakie Zygmunt III jednak ciągle wysyłał ze Szwecji, i powrót króla przed terminem rozwiały wszelkie złudzenia Zamoyskiego, że kiedykolwiek jeszcze będzie rządził przy boku Batorego. Sam o sobie jako przyszłym królu już nie myślał, bo choć teoretycznie mógł od marca 1590 r. po śmierci Gryzeldy spełnić warunek sine qua non ciągle żyjącej i pozostającej przecież formalnie nadal królem Anny I i ożenić się z młodszą siostrą Zygmunta III, to uznał najwyraźniej (i to nie tyle dopiero w czasie sejmu inkwizycyjnego, jak twierdzi Recenzent [0791], ale znacznie wcześniej, bo zaraz po wyborze Zygmunta, o czym już wspomniano), że wobec powszechnego oporu w Rzeczypospolitej wobec jego osoby, łatwiej zdoła przeforsować kandydaturę Batorego. Jego szwagier Zygmunt (podobnie jak wcześniej kardynał Andrzej) miał oczywiście wyrazić gotowość poślubienia Anny (zwanej w historiografii polskiej niesłusznie „Wazówną”, gdyż - jak już wspomniano - „Waza” to nie jest nazwisko królów szwedzkich, ani nawet źródłowo uzasadniony przydomek, lecz inwencja twórcza polskich historyków).

Nie mogę absolutnie zgodzić się Recenzentem, że „nie interesuje” mnie w monografii, (gdy przedstawiam wydarzenia sejmu inkwizycyjnego), „dlaczego Zygmunt III utrzymał się na tronie”, gdyż opisuję ,,jedynie wystąpienia senatorów i kolejne deklaracje królewskie", konkluduję „zaś stwierdzeniem: «Sejm inkwizycyjny, ostatnia wielka próba przejęcia władzy przez kanclerza, która miała się zakończyć sądem nad Zygmuntem III i jego detronizacją, zakończyła się totalnym fiaskiem»” (0791). Następne moje zdanie po tej konkluzji wszak brzmi następująco: „Królowi winy nie udowodniono, przy czym charakterystyczna była postawa szlachty krakowskiej, «że choćby z tej inkwizycji okazała się winność, jaka w osobie J. K. Mości, do ostrości prawa, które się zawiera w przysiędze Pańskiej de non praestanda oboedientia, przystępować nie będziemy, ale na poważnym napomnieniu Ordinum, któryby pewność poprawy nam sprawiło poprzestaniemy»"33. W przypisie do owego fragmentu Skryptu posłów krakowskich na sejmie 1592 mamy z kolei fragment laudum sejmiku

32 P.P. Szpaczyński, Wielkie poselstwo cesarza Rudolfa II na Sejm Rzeczypospolitej w 1593 r., Sobótka 67, 2012, 1, s. 83.

33 Skrypt posłów krakowskich na sejmie 1592, w: Dyaryusze i akta sejmowe r. 15911592, wyd. E. Barwiński, Kraków 1911, SRP, t. 21, s. 248-249. 
wiszeńskiego, w którym czytamy: „a jeśliby się kto praktykantem pokazał, takowego skarać, ochraniając jednak w tem dostojeństwo i przełożeństwo Króla JMci samego, któremu nad sobą długo fortunnego panowania życzymy”34. Dalej pada zdanie, iż: „W podobnym tonie wypowiedział się kardynał Radziwiłł: «na KJMci quis effectus, jeżeliby się pokazało: Onego sromocić same siebie sromocić, gdyż on głową, my jego członki jesteśmy»" "35. Wcześniej (S148) w monografii mamy zacytowane podobne opinie innych senatorów - biskupa płockiego Wojciecha Baranowskiego, wojewody trockiego Mikołaja Krzysztofa Radziwiłła „Sierotki” i marszałka wielkiego koronnego Andrzeja Opalińskiego.

Powyższe cytaty z monografii wskazują, iż to, co Recenzent określił jako „kluczowe” - jego zdaniem - dla utrzymania się Zygmunta III na tronie, a mianowicie „stanowisko zdecydowanej większości senatorów i posłów, którzy zdając sobie sprawę z powagi sytuacji, nie chcieli doprowadzić do nowej elekcji" (0791) jest również moją opinią. Dlatego nie zgadzam się, że Zygmunt III ponosił jakąkolwiek osobistą odpowiedzialność za podjęcie gry dyplomatycznej, która wbrew temu, co sądzi Recenzent, nie była wcale „niebezpieczna dla niego” (0792), (twierdzenia, że była „hazardowa” [0 794] i „nieomal doprowadziła go do utraty tronu polskiego" [0783] mają się wszak nijak do rzeczywistości). Tym bardziej nie była „niebezpieczna dla państwa” (0792), dla którego niebezpieczne było raczej dążenie Zamoyskiego do detronizacji króla poprzez rozpętywanie afery abdykacyjnej, o czym najlepiej wiedzieli senatorowie i szlachta, co przecież udowodnili na sejmie inkwizycyjnym.

Co do wywodu Opalińskiego, że Zamoyski po sejmie inkwizycyjnym: „Zmienił swoją postawę, jego późniejsze wystąpienia straciły ostrze antykrólewskie. Nastąpił wkrótce blisko dziesięcioletni okres współpracy króla z Zamoyskim. Owocem było zahamowanie ekspansji habsburskiej na Bałkanach i wspólna z monarchą polityka wobec planów ligi antytureckiej" (0791), to warto zauważyć, iż owa zmiana postawy (oprócz tego, o czym już wspomniano, że Zamoyski wreszcie zrozumiał po powrocie króla z koronacji w Szwecji, że Zygmunta III z Polski nigdy się nie pozbędzie) była w pierwszym rzędzie wynikiem zmiany postawy samego monarchy wobec kanclerza, o czym jest mowa w monografii (m.in. S172), a czego Recenzent zdaje się nie zauważać.

Reasumując kwestię działań Jana Zamoyskiego w latach 1587-1592, pragnę podkreślić, iż „dostrzegając poszczególne posunięcia hetmana”, co zauważył Recenzent, nie mogłem ,jednak połączyć ich” w spodziewaną

${ }^{34}$ Laudum sejmiku wiszeńskiego, Wisznia, 7 VIII 1592, w: AGZ, t. 20, s. 91.

35 SRP, t. 21, s. 213. 
przez Opalińskiego „spójną i logiczną całość” (0788, 792), gdyż owa całość, którą stworzył Recenzent w artykule recenzyjnym w odniesieniu do rzekomych zamierzeń kanclerza, odbyła się z ewidentnym przemilczeniem stanowiącej największe zagrożenie dla jej „spójności i logiczności" kluczowej kwestii Batorych, której pominąć przecież było nie sposób.

Na fakt, iż negatywny wizerunek Zygmunta III ciągle budził i nadal budzi sprzeciw, zwracam uwagę w monografii (S8). Wymieniam badaczy, którzy na przestrzeni wieków próbowali mu się przeciwstawić, wskazuję na tendencję w historiografii polskiej do przeciwstawiania się utartym poglądom na temat Zygmunta III, którą za słuszną uznaje coraz więcej współczesnych historyków. Ich poglądy prezentuję w rozdziale pierwszym a także w pozostałych trzech. Szkoda więc, że Recenzent nie podał żadnego przykładu na potwierdzenie swojego zarzutu, iż „korygując negatywny wizerunek monarchy w historiografii nie zawsze zauważam, że wizerunek króla już został w znacznym stopniu sprostowany" przez moich poprzedników $(0793,794)$. To oczywiście nie zmienia faktu, iż z określeniem „w znacznym stopniu” trudno mi się zgodzić. I nie jest to tylko moje zdanie. W tym samym roku co książka mojego autorstwa wydany został (przez portal Histmag.org) e-book Czy Zygmunt III Waza zasłużył na niesławę? Autorzy Anna Pieńkowska i Maciej Pieńkowski w pierwszym rozdziale „Władca zmitologizowany” piszą: „Powszechnie sądzi się, że historia panowania Zygmunta III została zweryfikowana, a stereotypy oraz przekłamania wyjaśniono i zastąpiono rzetelną wiedzą opartą na szerokiej bazie źródłowej. Nie jest to jednak prawda"36. Urszula Augustyniak również w tym samym roku we wstępie do wydania edycji źródeł antyklerykalnych z czasów Zygmunta III twierdzi, że król był „kryptojezuitą działającym pod dyktando kleru”, a wojnę z Moskwą, dzięki której monarcha po stu latach odzyskał m.in. Smoleńsk i rozszerzył granice Rzeczypospolitej do największych w jej historii, określa mianem „awanturniczej interwencji” ${ }^{37}$.

Negatywna ocena Zygmunta III jest tak mocno zakorzeniona w historiografii, że jedyne, co wydaje się większości badaczy dopuszczalne, to najwyżej podważenie absurdalnych zarzutów wobec króla, ale próba oczyszczenia z nich monarchy to już zakrawa na "skrajną idealizację" bądź wręcz „hagiografię”, czego twierdzenie Recenzenta, iż „gdyby

${ }^{36}$ Szerzej o tym, dlaczego nie jest to prawda, A. Pieńkowska, M. Pieńkowski, Czy Zygmunt III Waza zasłużł na niesławę?, Warszawa 2013, s. 11.

${ }^{37}$ U. Augustyniak, Państwo świeckie czy księże? Spór o rolę duchowieństwa katolickiego w Rzeczypospolitej w czasach Zygmunta III Wazy. Wybór tekstów, Warszawa 2013, s. 74, 111. 
poprzestano na przytoczeniu istotnych argumentów (a nie brak ich w monografii) podważających winę monarchy, efekt byłby osiągnięty" (0794), jest najlepszym przykładem.

Przy okazji omawiania każdego z sejmów pojawia się fraza, że sejm obradował „pod przewodnictwem w izbie”, po czym następuje imię i nazwisko marszałka. Raz w przypadku sejmu konwokacyjnego 1587 r. doprecyzowania „w izbie” rzeczywiście, wskutek przeoczenia, zabrakło. Imputowanie mi jednak w związku z tym braku świadomości, że wojewodzic płocki Stanisław Uchański nie kierował wówczas sejmem, tylko był marszałkiem izby poselskiej, wydaje się zbyt daleko idacce.

Nie mogę zgodzić się ze stwierdzeniem Opalińskiego, że w rozdziale drugim, w przypisie 243 się pogubiłem, gdyż to raczej - w mojej ocenie - Recenzent się pogubił i to nie tylko twierdząc, iż „przypis ten jest zbędny, gdyż w tym miejscu Autor omawia sytuację po klęsce arcyksięcia pod Byczyną” (0792). W przypisie tym podaję wszak: „W marcu $1588 \mathrm{r}$. przysięgę na wierność królowi Zygmuntowi III złożyli ostatni neutraliści na Rusi", co miało ewidentnie miejsce po klęsce arcyksięcia pod Byczyną (24 I 1588). W tym miejscu, mającym zilustrować, jak ostatecznie wnuk wnuka Jagiełły wyszedł zwycięsko z sytuacji, która zaistniała wskutek podwójnej elekcji, przypominam też, iż: „Zdominowana przez wpływy habsburskie Wielkopolska po koronacji Zygmunta III na zjeździe województwa poznańskiego i kaliskiego w Środzie 29 grudnia 1587 r. potwierdziła wcześniejszą deklarację z 19 września: «przy KJM Zygmuncie obranym [--] statecznie stać będziemy»". Tymczasem Recenzent interpretuje to opacznie twierdząc: „Jako przykład zdominowania Wielkopolski przez maksymilianistów w 1587 r. Autor podał uchwałę sejmiku średzkiego z 19 września”. I dodaje: „Tymczasem laudum to popiera w pełni królewicza Zygmunta, więcej, uchwalono w jego obronie pospolite ruszenie" (0792), tak jak gdyby przytoczonego cytatu: ,przy KJM Zygmuncie obranym [--] statecznie stać będziemy" w tym przypisie nie było, a następnie, pomijając pozostałą treść tegoż przypisu, który mówi o neutralistach na Rusi, stwierdza, iż przypis ten jest zbędny.

„Dwie pomyłki”, o których Recenzent pisze w odniesieniu do listów nuncjusza Annibale di Capua do kardynała Aleksandra Montalta (z 28 II 1588 i 27 III 1589) nie są bynajmniej - jak sądzi Opaliński - wynikiem „korzystania z edycji Przeździeckiego Listów Annibale di Capua zamiast z wydania J.W. Wosia" (0792). W kwestii pierwszego listu to między jedną a drugą edycją nie ma żadnej różnicy. Rzeczywiście - jak słusznie zauważył Recenzent - nuncjusz informował kardynała Montalto o pobycie arcyksięcia Maksymiliana w Krasnymstawie w liście z 28 lutego $1588 \mathrm{r}$. pisanym z Witowa, gdyż w liście z 10 lutego podaje jedynie, iż „Uradzono 
nareszcie, że nie wstępując do Krakowa, P. Kanclerz zaprowadzi N. Maksymiliana na Ruś do zamku zwanego Krasnymstawem"38.

W przypadku jednak „drugiego błędu”, o którym Recenzent pisze, iż ,jest poważniejszy”, gdyż „datacja listu nuncjusza z 27 marca 1589 r. do kardynała Montalto jest wprawdzie słuszna, ale treść inna. Nuncjusz w tym liście nie pisze bowiem, że król chciał zgody sejmu «na pobór powszechny» i zgody na wypowiedzenie wojny Moskwie, ale donosi o próbach czynionych przez protestantów w sprawie uchwalenia egzekucji do konfederacji warszawskiej" (0792), Opaliński się myli, gdyż najwyraźniej nie wie, iż Annibale di Capua tego samego dnia - 27 marca - skierował z Warszawy do kardynała Montalto dwa listy i treść drugiego z nich, która rozpoczyna się od słów: „Przystępuję teraz do zdania sprawy W.M. o tem co się traktowało w Senacie po dziś dzień, od rozpoczęcia Sejmu, dawszy wiadomość o mojem przybyciu tu i o innych szczegółach w tuż załączonym liście, pod tąż samą datą" zawiera w kolejnym zdaniu informację podaną w monografii, iż „propozycje ze strony Króla J. M. [--] zawierały głównie dwa punkta: naprzód żądanie poboru powszechnego; po wtóre wypowiedzenie wojny Moskwie"39. Opaliński nie mógł tego wiedzieć, gdyż korzystał z edycji Jana W. Wosia z 1984 r., w której został wydany jedynie pierwszy z listów nuncjusza z 27 marca 1589 r., drugi zaś został wydany w innej edycji tegoż samego autora, a mianowicie w roku $1992^{40}$. W wydaniu Przeździeckiego mamy obydwa listy po sobie, co Recenzent, o ile w ogóle z tej edycji korzystał, najwyraźniej przeoczył, koncentrując się jedynie na treści pierwszego z nich.

Nie sposób się zgodzić z Opalińskim, że w czasie obrad sejmu w $1600 \mathrm{r}$. "Jan Wodyński już dawno nie żył" (O792), Franciszek Siarczyński podaje wszak, iż „Wodyński Jan, Wojewoda Podlaski, wprzód Kasztelan Liwski [--] zszedł r. 1616" "41. W Spisach urzędników podlaskich XIV-XVIII wieku mamy „Wodyński h. Kościesza Jan pcz Podl. (1587-1589), sęd. Droh.

${ }^{38}$ Listy Annibala z Kapui, arcybiskupa neapolitańskiego nuncjusza w Polsce, o bezkrólewiu po Stefanie Batorym i pierwszych latach panowania Zygmunta III do wyjścia arcyksięcia Maksymiliana z niewoli..., tłum. i wyd. A. Przeździecki, Warszawa 1852, s. 116-117.

39 Ibidem, s. 189.

40 „Monsignor Vescovo di Premislia Vicecancelliere face la propositione da parte del Re, che conteneva in sostanza due capi: l'uno di chiedere la contributione generale et l'altro d'intimare la guerra al Mosco", Annibale di Capua al. card. Alessandro Montalto, Varsavia, 1589 marzo 27, w: Fonti per la storia della nuntiatura polacca di Annibale di Capua (1586-1591), wyd. J.W. Woś, Trento 1992, s. 160.

${ }^{41}$ F. Siarczyński, Obraz wieku panowania Zygmunta III, króla polskiego i szwedzkiego, zawierający opis osób żyjących pod jego panowaniem, znamienitych przez swe czyny pokoju $i$ wojny, cnoty lub występku, dzieła piśmienne, zasługi użyteczne i celne sztuki porządkiem abecadła ułożony, cz. 2, Lwów 1828, s. 317. 
(1591-1596), klan Podl. (1596-1613), wda Podl. 1613-1616, rzekomy klan liwski” ${ }^{2}$. Co do Szczęsnego Kryskiego zaś, to „nazywam” go „Feliksem” (0793), gdyż występuje on powszechnie w literaturze przedmiotu jako Feliks (a nie jako Szczęsny) ${ }^{43}$.

Zdanie (S227), że król w uniwersale (28 II 1607) potępiającym zjazd w Kole: „Apelował do zebranych, aby w spokoju oczekiwali na sejm, który będzie obradował od 7 maja do 18 czerwca pod przewodnictwem w izbie referendarza koronnego Feliksa Kryskiego", rzeczywiście, jak słusznie zauważył Recenzent, „dziwnie brzmi” (0793). Dziwnie za przyczyną słowa „będzie”, które jest tu ewidentnie zbędne, na co wskazuje jednak kontekst, gdyż z następnego zdania (na tej samej stronie 227) wprost wynika, że obrady już trwały: „Dnia 18 maja senat i izba poselska wezwała Mikołaja Zebrzydowskiego, aby przybył do Warszawy i opowiedział wszystko, co wie o niebezpieczeństwach grożących Rzeczypospolitej”. Wyciągać jednak z tego "dziwnie brzmiącego" i wyrwanego z kontekstu zdania tak daleko idące wnioski, że „monarcha na pięć tygodni przed sejmem miał informować szlachtę, kto będzie marszałkiem sejmu i że znał dokładną datę jego zakończenia", to rzeczywiście, używając określenia Recenzenta, „gruba przesada” (0793).

Co do innych zarzutów: ostania z wymienionych w spisie literatury publikacji autorstwa Haliny Michalak wskutek przeoczenia znalazła się rzeczywiście jako pierwsza pod nazwiskiem autora, którego publikacje wymieniono jako kolejne, nie oznacza to jednak, że w bibliografii „z H. Michalak uczyniono A. Michalka” (0793), gdyż H. Michalak tam przecież występuje. Pomyłki tego typu jak zaliczenie ostatniej z publikacji danego autora jako pierwszej do dzieł autora, który następuje po nim czy też błędny inicjał imienia danego autora (np. Ciara M. zamiast Ciara S. [0793]) są w bibliografii liczącej 40 stron praktycznie nie do uniknięcia.

Skróty występujące w monografii - „Kw. Hist.” dla „Kwartalnika Historycznego” i „Prz. Hist.” dla „Przeglądu Historycznego”, które Edward Opaliński określił jako „dziwne” (0793) są zgodne z „Wykazem skrótów instytucji, czasopism, publikacji, serii wydawniczych i wydawnictw źródłowych" umieszczonym w bazie cyfrowej bazhum.muzhp.pl, gromadzącej zawartość polskich czasopism humanistycznych i społecznych. Wykaz ów obowiązuje powszechnie, m.in. w takich czasopismach jak „Studia Źródłoznawcze” czy też „Średniowiecze Polskie i Powszechne”.

${ }^{42}$ Urzędnicy, t. 8, s. 196.

43 J. Maciszewski, Kryski Feliks (1562-1618), kanclerz wielki koronny, PSB, t. 15, 4, Wrocław 1970, s. 482-485; Kryski Feliks (Szczęsny), Urzędnicy, t. 10, s. 177; hasło w indeksie osób: Kryski Feliks, J. Byliński, op. cit., s. 248. 
Biog ram: dr Przemysław P. Szpaczyński - historyk i germanista; zainteresowania: stosunki Polski-Litwy z Habsburgami, Rosją i Szwecją-Finlandią w XVI-XVII w.; wpływ dominacji szlachty nad królem na politykę zagraniczną Polski-Litwy w okresie panowania dynastii Jagiellonów (w latach 1399-1668, czyli od samodzielnych rządów założyciela polsko-litewskiej dynastii Władysława II Jagiełły do abdykacji Jana II Kazimierza - ostatniego Jagiellona po kądzieli); przygotowuje biografię króla Zygmunta III; kontakt: p.szpaczyński@interia.eu. 